\title{
Plitidepsin has a positive therapeutic index in adult patients with COVID-19 requiring hospitalization
}

Authors: José F. Varona ${ }^{1,2 *}$, Pedro Landete ${ }^{3,4}$, Jose A. Lopez-Martin ${ }^{5}$, Vicente Estrada ${ }^{6,7}$, Roger Paredes $^{8,9}$, Pablo Guisado-Vasco ${ }^{10,11}$, Lucía Fernández de Orueta ${ }^{11,12}$, Miguel Torralba ${ }^{13,14}$, Jesús Fortún $^{15}$, Roberto Vates ${ }^{12}$, José Barberán ${ }^{1,2}$, Bonaventura Clotet ${ }^{8,9,16,17}$, Julio Ancochea ${ }^{3,4,18}$, Daniel Carnevali ${ }^{10,11}$, Noemí Cabello ${ }^{19}$, Lourdes Porras ${ }^{20}$, Paloma Gijón ${ }^{21}$, Alfonso Monereo ${ }^{12}$, Daniel Abad ${ }^{11,12}$, Sonia Zúñiga ${ }^{22}$, Isabel Sola ${ }^{22}$, Jordi Rodon ${ }^{23}$, Nuria Izquierdo-Useros ${ }^{24,25}$, Salvador Fudio $^{26}$, María José Pontes ${ }^{27}$, Beatriz de Rivas ${ }^{27}$, Patricia Girón de Velasco ${ }^{5}$, Belén Sopesén ${ }^{5,28,29}$, Antonio Nieto ${ }^{30}$, Javier Gómez ${ }^{30}$, Pablo Avilés ${ }^{31}$, Rubin Lubomirov ${ }^{26}$, Kris M. White $^{32,33}$, Romel Rosales ${ }^{32,33}$, Soner Yildiz ${ }^{32,33}$, Ann-Kathrin Reuschl ${ }^{34}$, Lucy G. Thorne ${ }^{34}$, Clare Jolly $^{34}$, Greg J. Towers ${ }^{34}$, Lorena Zuliani-Alvarez ${ }^{35,36,37,38}$, Mehdi Bouhaddou ${ }^{35,36,37,38}$, Kirsten Obernier ${ }^{35,36,37,38}$, Luis Enjuanes ${ }^{22}$, Jose M. Fernández-Sousa ${ }^{39}$, Plitidepsin - COVID - 19 Study Group ${ }^{\ddagger}$, Nevan J. Krogan ${ }^{32,35,36,37,38^{*}}$, José M. Jimeno ${ }^{5 \dagger}$, Adolfo García-Sastre ${ }^{32,33,40,41 \dagger^{*}}$.

Affiliations:

${ }^{1}$ Departamento de Medicina Interna, Hospital Universitario HM Monteprincipe, HM Hospitales, Madrid, Spain.

${ }^{2}$ Facultad de Medicina, Universidad San Pablo-CEU, Madrid, Spain.

${ }^{3}$ Hospital Universitario La Princesa, Madrid, Spain.

${ }^{4}$ Universidad Autónoma de Madrid, Madrid, Spain.

${ }^{5}$ Virology \& Inflammation Unit, PharmaMar, S.A., Colmenar Viejo, Madrid, Spain.

${ }^{6}$ Hospital Clínico San Carlos, Madrid, Spain.

${ }^{7}$ Universidad Complutense de Madrid, Madrid, Spain.

${ }^{8}$ Infectious Diseases Department, irsiCaixa AIDS Research Institute, Badalona, Barcelona, 25 Spain.

${ }^{9}$ Hospital Germans Trias I Pujol, Badalona, Barcelona, Spain.

${ }^{10}$ Internal Medicine Department. Hospital Universitario Quironsalud Madrid, Madrid, Spain.

${ }^{11}$ Universidad Europea, Madrid, Spain.

${ }^{12}$ Internal Medicine Department, Hospital Universitario de Getafe, Madrid, Spain.

${ }^{13}$ Health Sciences Faculty, University of Alcalá, Madrid, Spain.

${ }^{14}$ Guadalajara University Hospital, Guadalajara, Spain.

${ }^{15}$ Hospital Universitario Ramón y Cajal, Madrid, Spain.

${ }^{16}$ Universitat Autònoma de Barcelona, Barcelona, Spain.

${ }^{17}$ Universitat de Vic, Universitat Central de Catalunya Barcelona, Spain.

${ }^{18}$ Centro de Investigación en Red de Enfermedades Respiratorias (CIBERES), Instituto de Salud Carlos III (ISCIII), Madrid 
medRxiv preprint doi: https://doi.org/10.1101/2021.05.25.21257505; this version posted May 25, 2021. The copyright holder for this preprint (which was not certified by peer review) is the author/funder, who has granted medRxiv a license to display the preprint in perpetuity. All rights reserved. No reuse allowed without permission.

${ }^{19}$ Infectious Diseases Department, Clinico San Carlos University Hospital, Madrid, Spain.

${ }^{20}$ Internal Medicine, Hospital General de Ciudad Real, Ciudad Real, Spain.

${ }^{21}$ Clinical Microbiology and Infectious Diseases Department, Hospital General Universitario Gregorio Marañón, Instituto de Investigación Sanitaria Gregorio Marañón, Madrid, Spain.

${ }^{22}$ Department of Molecular and Cell Biology, Centro Nacional de Biotecnología (CNBCSIC), Madrid, Spain.

${ }^{23}$ IRTA, Centre de Recerca en Sanitat Animal (CReSA, IRTA-UAB), Campus de la UAB, Bellaterra, Spain

${ }^{24}$ IrsiCaixa AIDS Research Institute, Badalona, Barcelona, Spain.

${ }^{25}$ Germans Trias i Pujol Research Institute (IGTP), Badalona, Barcelone, Spain.

${ }^{25}$ Clinical Pharmacology Unit, PharmaMar, Colmenar Viejo, Madrid, Spain.

${ }^{27}$ Medical Affairs, PharmaMar, Colmenar Viejo, Madrid, Spain.

${ }^{28}$ Sylentis, S.A.U., Tres Cantos, Madrid, Spain.

${ }^{29}$ Biocross, S.L., Valladolid, Spain

${ }^{30}$ Bio Statistics Unit, PharmaMar, Colmenar Viejo, Madrid, Spain.

${ }^{31}$ Preclinical Unit, Pharmamar, Colmenar Viejo, Madrid, Spain.

${ }^{32}$ Department of Microbiology, Icahn School of Medicine at Mount Sinai, New York, NY, USA.

${ }^{33}$ Global Health Emerging Pathogens Institute, Icahn School of Medicine at Mount Sinai, New York, NY, USA.

${ }^{34}$ Division of Infection and Immunity, University College London, London WC1E 6BT, United Kingdom.

${ }^{35}$ Quantitative Biosciences Institute (QBI), University of California San Francisco, San Francisco, CA 94158, USA.

${ }^{36}$ J. David Gladstone Institutes, San Francisco, CA 94158, USA.

${ }^{37}$ Quantitative Biosciences Institute (QBI), Coronavirus Research Group (QCRG), San Francisco, CA 94158, USA.

${ }^{38}$ Department of Cellular and Molecular Pharmacology, University of California, San Francisco, CA 94518, USA.

${ }^{39}$ Pharmamar, Colmenar Viejo, Madrid, Spain.

${ }^{40}$ Department of Medicine, Division of Infectious Diseases, Icahn School of Medicine at Mount Sinai, New York, NY, USA.

${ }^{41}$ Tish Cancer Institute, Icahn School of Medicine at Mount Sinai, New York, NY, USA.

* Corresponding author. Email: jfvarona@hmhospitales.com (J.F.V.); Adolfo.GarciaSastre@mssm.edu (A.G-S.); Nevan.Krogan@ucsf.edu, (N.J.K.)

$\dagger$ These authors contributed equally to this work.

\$ A full list of the authors and affiliations included in the Supplementary Materials. 
medRxiv preprint doi: https://doi.org/10.1101/2021.05.25.21257505; this version posted May 25, 2021. The copyright holder for this preprint (which was not certified by peer review) is the author/funder, who has granted medRxiv a license to display the preprint in perpetuity.

All rights reserved. No reuse allowed without permission.

Abstract: Plitidepsin is a marine-derived cyclic-peptide that inhibits SARS-CoV-2 replication at low nanomolar concentrations by the targeting of host protein eEF1A (eukaryotic translationelongation-factor-1A). We evaluated a model of intervention with plitidepsin in hospitalized COVID-19 adult patients where three doses were assessed (1.5, 2 and $2.5 \mathrm{mg} /$ day for 3 days, as a 590 -minute intravenous infusion) in 45 patients (15 per dose-cohort). Treatment was well tolerated, with only two Grade 3 treatment-related adverse events observed (hypersensitivity and diarrhea). The discharge rates by Days 8 and 15 were $56.8 \%$ and $81.8 \%$, respectively, with data sustaining dose-effect. A mean $4.2 \log 10$ viral load reduction was attained by Day 15. Improvement in inflammation markers was also noted in a seemingly dose-dependent manner. These results suggest that plitidepsin impacts the outcome of patients with COVID-19.

One-Sentence Summary: Plitidepsin, an inhibitor of SARS-Cov-2 in vitro, is safe and positively influences the outcome of patients hospitalized with COVID-19.

Key Words: COVID-19 treatment, plitidepsin, eEF1A, SARS-CoV-2 
medRxiv preprint doi: https://doi.org/10.1101/2021.05.25.21257505; this version posted May 25, 2021. The copyright holder for this preprint (which was not certified by peer review) is the author/funder, who has granted medRxiv a license to display the preprint in perpetuity.

All rights reserved. No reuse allowed without permission.

\section{Introduction}

As of April 2021, there have been approximately 135 million confirmed cases of COVID-19 reported to the World Health Organization (WHO), including 3 million deaths. (1) The lack of effective antiviral therapies represents a glaring unmet need, not only for the treatment of the current severe acute respiratory syndrome coronavirus 2 (SARS-CoV-2) pandemic, (2) but also for potential future pandemics, which may originate from other emergent coronaviruses. (3-5)

Viruses, particularly single-stranded positive-sense RNA viruses, are ubiquitous in the sea, where they participate directly or indirectly in the population dynamics of marine organisms. (6) Thus, the sea may prove to be a reservoir of potent, naturally selected antiviral compounds.

One such compound, plitidepsin, is a cyclic depsipeptide originally isolated from a Mediterranean marine tunicate (Aplidium albicans) and is structurally related to didemnins, some of which (i.e., those isolated from Trididemnum solidum) have shown antiviral properties. $(7,8)$

Plitidepsin targets eukaryotic translation elongation factor 1A (eEF1A) (9), which is one of the most abundant protein synthesis factors in the eukaryotic cell, $(9,10)$ and a protein known to be used by viruses to facilitate their replication inside their host. (11) The SARS-CoV-2 nucleocapsid $(\mathrm{N})$ protein is a key element involved in packaging of the viral RNA genome, (12, 13) and interacts with eEF1A. This interaction might be essential for viral replication, as eEF1A knockdown results in a significant reduction in virus replication. $(12,13)$

Originally developed as a cancer treatment, plitidepsin has undergone an extensive clinical development program. Specifically, several phase I and II clinical trials have been conducted to explore different intravenous dosing schedules and infusion times (14-18). Pharmacokinetic and safety properties of plitidepsin were gathered from these studies. Based on the results obtained from a phase III clinical trial (ADMYRE) (19), the Australian Therapeutic Goods Administration (TGA) approved the combination of plitidepsin with dexamethasone for the treatment of patients with relapsed/refractory multiple myeloma in 2018. (20)

In this study, we describe the results from a Proof-of Concept clinical trial that explores the potential of plitidepsin as a therapy for patients hospitalized with COVID-19.

\section{Results}

We have evaluated the antiviral activity of plitidepsin against different coronavirus species, strains and variants (Materials and Methods). Treatment of Huh-7 cells with as little as 0.5nM of plitidepsin inhibited infection of a human coronavirus 229E expressing GFP (Figure 1A). A $10^{4}$ - fold decrease in SARS-CoV genomic RNA (gRNA) accumulation and a $10^{3}$-fold decrease in virus SARS-CoV titers were observed in VeroE6 cells treated with 50nM plitidepsin. (Figure $\mathrm{S} 1$ and Table S1). By comparison, and consistent with previous results $(10,21)$ plitidepsin showed nanomolar efficacy against SARS-CoV-2-induced cytopathic effects on Vero E6 cells with a half-maximal inhibitory concentration $\left(\mathrm{IC}_{50}\right)$ of $0.038 \mu \mathrm{M}$, at concentrations where no cytotoxic effects were observed $\left(\mathrm{CC}_{50} 2.9 \mu \mathrm{M}\right)$ (Figure 1B). Moreover, plitidpesin maintained its nanomolar potency against replication of early as well as recently emerging SARS-CoV-2 lineages, such as B.1.1.7, in human lung and gastrointestinal cell lines (Figure 1C). Noteworthy, plitidepsin was more effective against both variants than remdesivir (Figure 1C).

To identify target human plasma concentrations of plitidepsin for SARS-CoV-2 infection we developed an extrapolation from in vitro results, in line with current recommendations. (22) This 
medRxiv preprint doi: https://doi.org/10.1101/2021.05.25.21257505; this version posted May 25, 2021. The copyright holder for this preprint (which was not certified by peer review) is the author/funder, who has granted medRxiv a license to display the preprint in perpetuity.

All rights reserved. No reuse allowed without permission.

approach integrated results from non-clinical studies described under Material and Methods (Supplement), including in vitro drug sensitivity data for SARS-CoV-2 in Vero cells, human plasma protein binding data (98\%) (Table S2), and in vivo tissue distribution data in rats (lungto-plasma partition coefficient ratio of 543-fold (Table S3).

The target plasma and lung concentrations for plitidepsin were initially based on in vitro data obtained by Boryung Pharmaceuticals, stablishing IC 50 of $3.26 \mathrm{nM}$ and $\mathrm{IC}_{90}$ of $9.38 \mathrm{nM}$ (Material \& Methods). A validated pharmacokinetic population model of plitidepsin (23) was used to simulate plasma exposures at different dose levels and infusion durations, so that plitidepsin plasma profiles would reach $0.33 \mu \mathrm{g} / \mathrm{L}$, and $0.96 \mu \mathrm{g} / \mathrm{L}$, assuring target concentrations in lung above the aforementioned in vitro $\mathrm{IC}_{50}$ and $\mathrm{IC}_{90}$. A 3-day daily schedule was initially selected to achieve sustained active exposures, under the hypothesis that an acute reduction of the viral load would prevent the onset of the more severe inflammatory phase of COVID-19. The predicted plasma concentrations of plitidepsin, at a dose of $1.5 \mathrm{mg}$ infused intravenously over $90 \mathrm{~min}$, were above the target $\mathrm{IC}_{50}$ for the full treatment period and above the $\mathrm{IC}_{90}$ for half of the treatment period. The respective predictions after a dose of $2.5 \mathrm{mg}$ were above the $\mathrm{IC}_{90}$ during most of the treatment period (Figure 2). Thus, we anticipated that the proposed range of doses would result in stable active concentrations in critical anatomical compartments, such as lung, for more than 120 hours. This model was later supported by White et al, who reported an IC 90 of $0.88 \mathrm{nM}(10)$. To reach this target concentration in lung tissue, according to the above reasoning, plitidepsin plasma concentration should be above $0.18 \mu \mathrm{g} / \mathrm{L}$.

We subsequently designed the APLICOV-PC study [APL-D-002-20; EudraCT \#2020-00199331; NCT \#04382066] as a proof-of-concept clinical trial, exploring three dose levels of plitidepsin (1.5 mg/day, $2.0 \mathrm{mg} /$ day, and $2.5 \mathrm{mg} /$ day, flat doses) for 3 consecutive days, as a 90min intravenous (IV) infusion, in adult patients with COVID-19 who required hospitalization. The primary endpoints were related to safety, but secondary efficacy and pharmacodynamic endpoints were also included (Material and Methods).

Enrollment began on May 12, 2020 and the study was completed by November 26, 2020. Here, we present the data analyses by the cut-off date of December 10, 2020.

In total, 46 hospitalized COVID-19 patients were enrolled across 10 sites in Spain. Baseline demographic and clinical characteristics are summarized in Table 1. One patient withdrew consent before initiating study-specific procedures. The 45 patients who received treatment were sequentially allocated to one of the three dose cohorts; whenever more than 1 dose cohort was open, a patient was assigned by central randomization (Material and Methods).

Forty-four patients completed the study through day 31, with one patient in the $1.5 \mathrm{mg}$ cohort withdrawing from the study after the first infusion due to a grade 3 hypersensitivity reaction. The average patient age was 52 years (range 31-84 years). Most patients were male (66.7\%) and 80\% had co-morbidities ( $46.7 \%$ had two or more). The most commonly reported comorbidities were obesity (22.2\%), hypertension (20\%), and type 2 diabetes mellitus (17.8\%). The distribution of comorbidities was similar between the three treatment cohorts.

Most patients had moderate COVID-19 (51.1\%), according to FDA categorization (24), with $13.3 \%$ and $35.6 \%$ having mild and severe disease, respectively. Baseline chest X-rays showed evidence of lower respiratory infection (infiltrates, unilateral pneumonia, or bilateral pneumonia) in 41 of 45 treated patients (91\%), with bilateral pneumonia seen in 32 of them (71\%); the percentage of patients with bilateral pneumonia was similar across dose cohorts. Viral load was similar across the three cohorts, with average baseline values for SARS-CoV-2 RNA from 
medRxiv preprint doi: https://doi.org/10.1101/2021.05.25.21257505; this version posted May 25, 2021. The copyright holder for this preprint (which was not certified by peer review) is the author/funder, who has granted medRxiv a license to display the preprint in perpetuity.

All rights reserved. No reuse allowed without permission.

nasopharyngeal samples of $6.1 \log _{10}$ copies/mL as measured by quantitative reverse transcriptase polymerase chain reaction (qRT-PCR).

Overall, plitidepsin treatment was well tolerated. As noted above, 1 patient discontinued treatment after a grade 3 hypersensitivity reaction to the first infusion of plitidepsin. The study protocol was thereafter amended to include IV premedication with dexamethasone $8 \mathrm{mg}$ and antihistamine drugs (anti-H1 and anti-H2), 30-min before the infusion of the study drug.

All 45 of the treated patients were evaluable for safety. Nearly all (44 of 45) patients experienced one or more adverse event (AEs). These AEs were determined to be treatment related in only 25 patients $(55.5 \%)$. Regardless of causality, 14 (31\%) patients experienced at least one Grade $\geq 3$ AE according to National Cancer Institute - Common Toxicity Criteria for Adverse Events, version 5.0 (NCI-CTCAE v5). The prevalence of grade 3-4 AEs was $40.0 \%$ in the $2.5 \mathrm{mg}$ cohort, $20.0 \%$ in the $2.0 \mathrm{mg}$ cohort, and $33.3 \%$ in the $1.5 \mathrm{mg}$ cohort. Though almost all Grade $\geq 3$ AEs were attributed to COVID-19, two Grade 3 AEs were attributed to plitidepsin: one case each of anaphylactic reaction (at $1.5 \mathrm{mg} /$ day) and diarrhea (at $2.5 \mathrm{mg} /$ day). No Grade 4 AEs were reported in patients receiving plitidepsin.

Table 2 presents the frequency of treatment-related AEs in this study. The following treatmentrelated AEs occurred in more than one patient: nausea (42.2\%), vomiting (15.6\%), diarrhea (6.7\%), abdominal pain (4.4\%), dizziness (4.4\%), and dysgeusia (4.4\%). These events were all mild to moderate (Grade 1-2) except the one case of Grade 3 diarrhea described above. The implementation of the aforementioned protocol amendment was associated with a reduction in the proportion of patients with nausea (from $55.6 \%$ to $38.9 \%$ ) and vomiting (from $22.2 \%$ to $13.9 \%)$. No new hypersensitivity reactions were seen in any of the 36 patients treated after the amendment (108 infusions).

Several laboratory abnormalities were reported in these patients, most of which were consistent with the acute, inflammatory nature of COVID-19. Of note, plitidepsin did not show signs of clinically relevant hemotoxicity; there were two patients with neutropenia (one Grade 1 and another Grade 2). An isolated observation of Grade 3 neutropenia was reported in an asymptomatic outpatient on the Day 31 follow-up; this patient was also taking metamizole, and the responsible investigator deemed that the event was neither clinically relevant nor related to plitidepsin. Of the 32 patients who entered with normal platelet counts, only one had Grade 1 thrombocytopenia, whereas of the 12 patients who entered into the study with Grade 1 thrombocytopenia, 5 (41.7\%) had counts normalized.

Abnormalities in liver function tests were common, transient, mild and reversible. Elevation of alanine aminotransferase (ALT) and aspartate aminotransferase (AST) were reported in 29 of 44 $(66 \%)$ and 13 of $44(30 \%)$ patients, respectively. Two patients had a single and self-limited observation of a Grade 3 increase in ALT, with no associated increase in bilirubin. Four patients of the 42 who entered with normal creatinine developed a Grade 1 increase in creatinine on study. A Grade 1 increase in creatinine phosphokinase (CPK) was documented in 3 of 37 patients $(8.1 \%)$ who had normal baseline values, whereas 4 of 5 patients $(80 \%)$ who entered with Grade 1-2 elevation had their CPK values decreased on study.

Hyperglycemia was documented in 8 of 45 patients (18\%): 3 patients in the $1.5 \mathrm{mg} /$ day dose cohort, 2 patients in the $2 \mathrm{mg} / \mathrm{day}$, and 3 patients in the $2.5 \mathrm{mg}$ /day group. All cases of hyperglycemia were Grade $\leq 2$ except one patient, who had Grade 3 hyperglycemia lasting for 2 days. For 5 patients, hyperglycemia was considered related to concomitant medication. None of these events were considered to be related to plitidepsin. 
medRxiv preprint doi: https://doi.org/10.1101/2021.05.25.21257505; this version posted May 25, 2021. The copyright holder for this preprint (which was not certified by peer review) is the author/funder, who has granted medRxiv a license to display the preprint in perpetuity.

All rights reserved. No reuse allowed without permission.

Three patients in this study died (6.7\%); all had severe disease at baseline, and each death was determined to be related to COVID-19. Deaths occurred on Days 22, 30 and 57 after the start of treatment with plitidepsin. One patient received plitidepsin $1.5 \mathrm{mg} / \mathrm{day}$ and the other two received $2.5 \mathrm{mg} /$ day, with no reported tolerability issues.

Seven additional patients experienced serious AEs (SAEs): five dosed at $1.5 \mathrm{mg} / \mathrm{day}, 1$ dosed at $2.0 \mathrm{mg} / \mathrm{day}$, and $1 \mathrm{dosed}$ at $2.5 \mathrm{mg} / \mathrm{d}$. As previously mentioned, only one SAE (2.2\% subjects) was considered related to the study drug: a Grade 3 hypersensitivity reaction occurring 5 minutes after the start of the first infusion of plitidepsin. This patient was withdrawn from the study before completing the full treatment.

All 44 patients who completed the 3-day treatment with plitidepsin were evaluated for efficacy analyses. Overall, the discharge rates by Days 8 and 15 after the start of plitidepsin were $56.8 \%$ (25 of 44) and $81.8 \%$ (36 of 44), respectively. Likewise, a mean $-4.2 \log _{10}$ reduction in viral load from baseline was attained by Day 15 . Without adjusting for any covariates and with the constraints of the small sample size, there was not a clear dose effect on discharge rates at Day 15: 78.6\% (1.5 mg/day), 93.3\% (2 mg/day) and 73.3\% (2.5 mg/day). Notably, the proportion of patients achieving hospital discharge by Day 8 seemed to increase with dose, from $42.9 \%$ for those receiving $1.5 \mathrm{mg} / \mathrm{day}$ to $60 \%$ and $66.7 \%$ for those receiving 2 and $2.5 \mathrm{mg} /$ day, respectively (Table S4).

Figure 3A plots the length of the hospitalization and time in the intensive care unit (ICU) per subject, dose and severity of the disease. As expected, the length of hospitalization was greater in patients with severe disease at baseline. The median time to discharge was 7 days (interquartile range [IQR]: 7-9 days) in patients with mild COVID-19, 7 days (IQR: 6-8 days) with moderate COVID-19, and 14 days (IQR: 7-26 days) with severe COVID-19 at baseline (log-rank $\mathrm{p}=0.001)$ (Figure 3B). The discharge rate by Day 15 was $95.7 \%$ (22 of 23) in patients with moderate disease compared with $53.3 \%$ (8 of 15) in patients with severe disease, and $100 \%$ (6 of 6) in patients with mild disease. Similarly, the discharge rate by Day 8 was $73.9 \%$ (17 of 23) in patients with moderate disease compared with $27 \%$ (4 of 15) in patients with severe disease, and $66.7 \%$ (4 of 6) in patients with mild disease.

Non-mechanical invasive ventilation was required in one patient with moderate disease $(4.3 \%)$ and in seven patients with severe disease $(46.7 \%)(\mathrm{p}=0.003)$. Six patients required intensive care support (13.6\%), all of whom had severe disease at baseline (6 of 15, 40\%). Tables S4 - S6 summarize additional outcome measures.

Most patients in this study presented with moderate COVID-19 at baseline. All patients in this subgroup ( 8 of 8 ) who were allocated to the highest dose level ( $2.5 \mathrm{mg} / \mathrm{day})$ were discharged by day 8 , whereas 3 of 7 patients $(43 \%)$ and 3 of 8 patients (38\%) treated at $2.0 \mathrm{mg} /$ day and 1.5 $\mathrm{mg} /$ day, respectively, were discharged beyond that time point. These data are visualized in Figure 3D, which shows that for patients with moderate disease who received plitidepsin 2.5 $\mathrm{mg} / \mathrm{day}$, the most probable duration of hospitalization was approximately 1 week with narrow variation with respect to the other doses.

While on study, 64.4\% (29 of 45) of patients received systemic corticosteroids, besides its use as pre-medication. After completing plitidepsin treatment, 15.5\% (7 of 45) of patients received additional treatments for COVID-19, including the anti-viral agent remdesivir (1 patient) and/or the anti-IL-6 monoclonal antibody tocilizumab (6 patients). 
medRxiv preprint doi: https://doi.org/10.1101/2021.05.25.21257505; this version posted May 25, 2021. The copyright holder for this preprint (which was not certified by peer review) is the author/funder, who has granted medRxiv a license to display the preprint in perpetuity.

All rights reserved. No reuse allowed without permission.

After their treatment, patients' viral loads were evaluated by RT-PCR. Viral load showed mean declines from baseline of 1.67, 2.84, and $4.24 \log _{10}$ copies/mL at days 4,7 , and 15, respectively (Table S4; see also Table S7 for individual assessments). The mean time to undetectable viral load was 13 days, longer in patients with severe disease at baseline (15 days) respect to mild or moderate disease (12 days) (Figure 3C). In the primary analysis, there were no significant differences in change to viral load across dose levels (Figure S4).

Baseline viral load was found to be significantly correlated with hospital discharge by Day 15, by logistic and Cox regression models. This occurred despite the limitations for modeling (due to the small number of patients [ $\mathrm{N}=44]$ and the high percentage of patients [82\%] discharged by Day 15), following a stepwise selection of covariates with a p-value $<0.10$ in univariate logistic models. As it looked like Day 8 could be more informative and discriminative for a new drug in COVID-19, as well as more relevant from a clinical point of view, a new post-hoc model was built. Twenty-nine patients $(64.4 \%)$ had a favorable outcome. Given the small sample size, the baseline variables we selected for exploratory purposes were limited to age, viral load, disease severity, and dose cohort. Figure 3E shows the coefficients and Forest Plot for this model. Again, increased baseline viral load significantly correlated with decreased hospital discharge rate by Day 8. Notwithstanding, allocation to the plitidepsin $2.5 \mathrm{mg} /$ day dose cohort and a younger age had higher probabilities of positive outcome, with the constraints of small sample size.

As the cohort of patients with moderate COVID-19 at baseline was the largest, and given that the above model assigned to the variable 'dose of plitidepsin' a marginally predictive weight, we focused on that category to capture hints of dose-related activity with which hypotheses could be built for future development of plitidepsin. Although statistical analyses were not performed, due to the small sample size, visual exploration of mean trends do not appear to capture dosedependent differences in the kinetics of viral PCR, in the moderate COVID-19 subgroup (Figure 4I). Nevertheless, it suggests that the higher the dose of plitidepsin, the smaller the peak of Creactive protein at day 7 (Figure $4 \mathrm{H}$ ), the faster the increase in lymphocyte count (Figure 4G), and the faster the recovery of neutrophil-to-lymphocyte ratio (Figure 4J), D-Dimer (Figure 4K), and in the score of a 6-ordinal scale for outcome (Figure 3F and Figure S6).(25) These findings may reflect immunomodulatory/anti-inflammatory effects, that could be either secondary to the reduction in viral load or plitidepsin-mediated, and might participate in the rapid recovery of lung infiltrates reported in some patients with computed tomography scan evaluations (Figure $4 \mathrm{ABC})$.

\section{Discussion}

Since late 2019, the world has been coping with a global health threat caused by the novel coronavirus, SARS-CoV-2. More than one year after being officially declared a pandemic, substantial disease burden remains, as the clinical course from severe lung involvement, evolving to respiratory failure continues to be the main cause of death for patients with COVID-19 patients.

Despite worldwide efforts to identify new treatments, as of this publication, no highly effective antiviral therapy against SARS-CoV-2 is yet available. Several strategies have been attempted with limited effect (26). One large collaborative effort systematically mapped the interactome between SARS-CoV-2 proteins and human proteins, identifying several dozens of potentially druggable interactions (27). Notably, the authors highlighted the potent antiviral effects 
medRxiv preprint doi: https://doi.org/10.1101/2021.05.25.21257505; this version posted May 25, 2021. The copyright holder for this preprint (which was not certified by peer review) is the author/funder, who has granted medRxiv a license to display the preprint in perpetuity.

All rights reserved. No reuse allowed without permission.

following the inhibition of eEF1A, which had been previously described as the target of plitidepsin (9).

In the set of preclinical studies of this and previous reports, plitidepsin showed strong antiviral activity and a positive therapeutic index in in vitro models of SARS-CoV-2 infection, with better performance than other drugs, including remdesivir $(10,28)$. In our study, regardless of the coronavirus species (HCoV 227E, SARS-CoV, SARS-CoV-2), the host cells, or the quantifying method used, highly consistent results were obtained, with the $\mathrm{IC}_{50}$ of plitidepsin always being in the nanomolar range. Notably, a similar in vitro antiviral effect was induced by plitidepsin against the B.1.1.7 variant of SARS-CoV-2 (firstly detected in the United Kingdom), which is known to bear several mutations affecting the viral spike protein that facilitates viral entry through its interaction with the human ACE2 receptor (29).

Using a drug-resistant mutant host factor, White et al. demonstrated that the potent in vitro activity of plitidepsin against SARS-CoV-2 was mediated through eEF1A inhibition (10). In addition, they also showed strong antiviral activity in vivo, characterized by a significant reduction in the viral load in lungs, as well as a clear reduction of alveolar and peribronchial inflammation. In addition, their data also supported a 3-day schedule, as the one used in this clinical study $(10)$.

Treatment with plitidepsin was well tolerated, with most adverse events being mild and transient in nature. There was no relevant hemotoxicity observed in this study. The proportion of laboratory abnormalities was consistent with the expected in COVID-19 patients. (30)

The death rate in our study was $6.7 \%$, and was related to COVID-19. A recently published metaanalysis on 33 studies on COVID-19 (totaling 13,398 patients, excluding critical care-only studies), estimated that in hospitalized patients the mortality rate was $11.5 \%$ (95\% CI: $7.7-16.9 \%)(31)$. Published data from large retrospective studies on patients admitted into Spanish hospitals report death rates between 20-28\% (32-36). It should be noted, however, that these analyses were performed on data extracted from the first epidemic wave, and APLICOV$\mathrm{PC}$ was run during the second wave, which might account in differences in the availability of health resources, learning curve, and baseline severity of hospitalized patients.

Efficacy data gathered from this clinical trial were in agreement with the preclinical antiviral activity of plitidepsin described above. Patients treated with plitidepsin showed rapid reduction in viral load (compared to their baseline value), reduction in biomarkers associated to inflammatory processes, and improvements in pneumonia. Each of these outcomes very likely contributed to mitigating disease progression and leading to an earlier discharge from the hospital.

The antiviral mechanism of plitidepsin may represent significant advantages in the treatment of COVID-19. Specifically, the likelihood of developing treatment-resistant SARS-CoV-2 strains seems to be remote given that plitidepsin does not directly target a viral component. Therefore, SARS-CoV-2 variants that carry mutations to viral components may be equally sensitive to plitidepsin treatment. Morevoer, patients treated with plitidepsin showed a rapid reduction in viral load by RT-PCR. This result needs to be confirmed in larger clinical trials that include a placebo control.

Elevation of inflammation markers such as C-reactive protein is associated with an increased risk of disease severity and mortality $(37,38)$. In this regard, it is noteworthy that in patients with moderate COVID-19 at baseline, intra-patient variations of inflammation markers trended 
medRxiv preprint doi: https://doi.org/10.1101/2021.05.25.21257505; this version posted May 25, 2021. The copyright holder for this preprint (which was not certified by peer review) is the author/funder, who has granted medRxiv a license to display the preprint in perpetuity.

All rights reserved. No reuse allowed without permission.

favorably with higher doses of plitidepsin, which may suggest a drug-effect. These observed changes in inflammatory biomarkers may partly explain the rapid clearance of lung infiltrates observed in chest imaging (Figure 4AB), and is in line with the preclinical observations reported by White et al. that treatment with plitidepsin prevents severe lung inflammation. (10) (Figure 4CDE)

Translational research on chronic lymphocytic leukemia has identified that plitidepsin can induce cytotoxicity in monocytes at nanomolar concentrations that have little effect in normal lymphocytes (39). Monocytes and macrophages may be infected by SARS-CoV-2, which results in an impairment of the adaptive immune responses against the virus, virus spread, and local tissue inflammation, mediated by the production of large amounts of pro-inflammatory cytokines and chemokines (40). We hypothesize that plitidepsin, besides acting as an antiviral agent, may also modulate immune response by its effects on monocytes/macrophages.

Plitidepsin was hypothesized to hold potential benefits against corona viruses, and therefore SARS-COV-2. This hypothesis was first successfully tested in various in vitro work. This led to in vivo tests which again demonstrated high potency in inhibiting SARS-CoV-2. We now report a proof-of-concept clinical study, showing the safety of administering plitidepsin at the doses and duration described, and supporting a therapeutic benefit of the treated patients. Nevertheless, our study has several limitations, including the small number of patients evaluated, the large variability, and the lack of a control group. These characteristics are likely limiting the observation of evident dose-response effects. An international controlled phase 3 trial exploring the efficacy and safety of plitidepsin in hospitalized patients with moderate COVID-19 (NEPTUNO; NCT04784559) has already received initial regulatory authorization in UK and several other European countries, the latter through a Voluntary Harmonisation Procedure [VHP1842 (VHP2021019)]. In summary, we have integrated preclinical and clinical studies on the use of plitidepsin to treat SARS-CoV-2 and other coronavirus infections, and generated promising patient data supporting the launching of phase 3 clinical studies to demonstrate the efficacy of treatment with plitidepsin in moderate COVID-19 patients.

Acknowledgments: We are indebted to the women and men that gave their consent to participate in this study, and to their relatives, for understanding their decision in these exceptional circumstances. We would like to thank Pascal Besman for his input, Timothy Silverstein for providing editorial support, and Lorena Martin Peña for technical and secretarial assistance. The full clinical research teams at each one of the participating sites have played an instrumental role. We recognize hard work and commitment done by Paz Cañadas, Daniel Sánchez-Brualla and Carlota Costa from Synlab Diagnósticos Globales, S.A.U. as central laboratory in charge of viral load characterization. We appreciate the collaboration with Boryung Pharmaceuticals in the first in vitro study on the activity of plitidepsin in SARS-CoV-2 infection models. We thank R. Albrecht for support with the BSL3 facility and procedures at the Icahn School of Medicine at Mount Sinai, New York.

Funding: This study has been funded by Pharmamar, S.A. (Madrid, Spain). This work was supported by grants from the Government of Spain (PIE_INTRAMURAL_LINEA 1 202020E079; PIE_INTRAMURAL_CSIC-202020E043). The research of CBIG consortium (constituted by IRTA-CReSA, BSC, \& IrsiCaixa) is supported by Grifols pharmaceutical. We also acknowledge the crowdfunding initiative \#Yomecorono (https://www.yomecorono.com). N.I.U. has non-restrictive funding from PharmaMar to study 
medRxiv preprint doi: https://doi.org/10.1101/2021.05.25.21257505; this version posted May 25, 2021. The copyright holder for this preprint (which was not certified by peer review) is the author/funder, who has granted medRxiv a license to display the preprint in perpetuity.

All rights reserved. No reuse allowed without permission.

the antiviral effect of Plitidepsin. N.J.K. was funded by grants from the National Institutes of Health (P50AI150476, U19AI135990, U19AI135972, R01AI143292, R01AI120694, and P01AI063302); by the Excellence in Research Award (ERA) from the Laboratory for Genomics Research (LGR), a collaboration between UCSF, UCB, and GSK (\#133122P); by the Roddenberry Foundation, and gifts from QCRG philanthropic donors. This work was supported by the Defense Advanced Research Projects Agency (DARPA) under Cooperative Agreement \#HR0011-19-2-0020. The views, opinions, and/or findings contained in this material are those of the authors and should not be interpreted as representing the official views or policies of the Department of Defense or the U.S. Government. This research was partly funded by CRIP (Center for Research for Influenza Pathogenesis), a NIAID supported Center of Excellence for Influenza Research and Surveillance (CEIRS, contract \# HHSN272201400008C), by DARPA grant HR0011-19-2-0020, by supplements to NIAID grants U19AI142733, U19AI135972 and DoD grant W81XWH-20-1-0270, and by the generous support of the JPB Foundation, the Open Philanthropy Project (research grant 2020-215611 (5384)), and anonymous donors to AG-S. S.Y. received funding from a Swiss National Foundation (SNF) Early Postdoc Mobility fellowship (P2GEP3_184202).

\section{Author contributions:}

J.F.V., P.L., V.E., R.P., P.G.V., L.F.O., M.T., J.F., R.V., J.B., B.C., J.A., D.C., N.C., L.P., P.G., A.M., D.A. had the role of clinical investigators and participated in patient selection, informed consent, protocol treatment and procedures, local team coordination.

J.B., V.E., J.F. had the role of Coordinating Principal Investigators for APLICOV-PC Clinical Study.

L.E., I.S., S.Z., J.R., N.I.U., S.Y., R.R, K.M.W., N.J.K., L.Z.A., M.B., K.O., A.K.R., L.G.T., C.J., G.J.T., A.G.S conducted cardinal non-clinical research that have either been a guide in the design and execution of this Clinical Trial or are strongly linked to further clinical development.

S.F., M.J.P., B.R., B.S., A.N., J.G., P.G.V, P.A., R.L. were involved in study design, therapeutic intervention modeling, protocol edit and amendments, follow-up and data analysis and coordinators of external translations and studies.

J.M.J., J.A.L.M., J.M.F.S. intervened in the hypothesis, design of the therapeutic model, oversight and design of the statistical analysis and data visualization.

Final study report coordinated by J.A.L.M. and J.M.J.

First draft of the article was produced by J.A.L-M and J.M.J. Major reviewers were P.A, S.F., J.M.F-S, V.E., J.F.V, N.J.K. and A.G-S

The clinical study was conducted within the frame of good clinical practice; Ápices Soluciones, S.L. acted as the Contract Research Organization, in charge of operations, logistics, data monitoring, and data management. 
medRxiv preprint doi: https://doi.org/10.1101/2021.05.25.21257505; this version posted May 25, 2021. The copyright holder for this preprint (which was not certified by peer review) is the author/funder, who has granted medRxiv a license to display the preprint in perpetuity.

All rights reserved. No reuse allowed without permission.

\section{Supplementary Materials}

Materials and Methods

Figures S1-S6

Tables S1-S7

References (1-11) 
medRxiv preprint doi: https://doi.org/10.1101/2021.05.25.21257505; this version posted May 25, 2021. The copyright holder for this preprint (which was not certified by peer review) is the author/funder, who has granted medRxiv a license to display the preprint in perpetuity.

All rights reserved. No reuse allowed without permission.

Table 1. Patients' Baseline Characteristics

\begin{tabular}{|c|c|c|c|}
\hline Parameter & $1.5 \mathrm{mg} / \mathrm{day}^{\mathrm{a}}$ & $2 \mathrm{mg} /$ day $^{\mathrm{a}}$ & $2.5 \mathrm{mg} / \mathrm{day}^{\mathrm{a}}$ \\
\hline Age (years) ${ }^{b}$ & $51(32-75)$ & $49(34-71)$ & $53(31-84)$ \\
\hline \multicolumn{4}{|l|}{ Gender - N (\%) } \\
\hline Male & $11(73.3 \%)$ & $11(73.3 \%)$ & $8(53.3 \%)$ \\
\hline Female & $4(26.7 \%)$ & $4(26.7 \%)$ & $7(46.7 \%)$ \\
\hline \multicolumn{4}{|l|}{ Ethnic Group - N (\%) } \\
\hline White & $13(86.7 \%)$ & $9(60 \%)$ & $9(60 \%)$ \\
\hline Latino & $2(13.3 \%)$ & $4(26.7 \%)$ & $6(40 \%)$ \\
\hline Asian & $0(0 \%)$ & $1(6.7 \%)$ & $0(0 \%)$ \\
\hline Arab & $0(0 \%)$ & $1(6.7 \%)$ & $0(0 \%)$ \\
\hline Time from symptom onset to first administration(days $)^{b}$ & $6(3-10)$ & $6(3-10)$ & $6(2-10)$ \\
\hline \multicolumn{4}{|l|}{ Comorbidities - N (\%) } \\
\hline One & $2(13.3 \%)$ & $7(46.7 \%)$ & $6(40 \%)$ \\
\hline Two or more & $8(53.3 \%)$ & $6(40 \%)$ & $7(46.7 \%)$ \\
\hline Hypertension & $2(13.3 \%)$ & $2(13.3 \%)$ & $5(33.3 \%)$ \\
\hline Heart disease & $1(6.7 \%)$ & $0(0 \%)$ & $1(6.7 \%)$ \\
\hline $\mathrm{COPD}^{\mathrm{c}}$ & $1(6.7 \%)$ & $1(6.7 \%)$ & $1(6.7 \%)$ \\
\hline Asthma & $2(13.3 \%)$ & $0(0 \%)$ & $3(20 \%)$ \\
\hline Kidney disease & $0(0 \%)$ & $1(6.7 \%)$ & $0(0 \%)$ \\
\hline Diabetes & $1(6.7 \%)$ & $5(33.3 \%)$ & $2(13.3 \%)$ \\
\hline Obesity & $1(6.7 \%)$ & $5(33.3 \%)$ & $4(26.7 \%)$ \\
\hline \multicolumn{4}{|l|}{ Disease severity at entry - $\mathrm{N}(\%)(24)$} \\
\hline Mild COVID-19 & $2(13.3 \%)$ & $3(20 \%)$ & $1(6.7 \%)$ \\
\hline Moderate COVID-19 & $8(53.3 \%)$ & $7(46.7 \%)$ & $8(53.3 \%)$ \\
\hline Severe COVID-19 & $5(33 \%)$ & $5(33 \%)$ & $6(40 \%)$ \\
\hline \multicolumn{4}{|l|}{$\mathrm{SpO}_{2}$ at room air - $\mathrm{N}(\%)$} \\
\hline$>93 \%$ & $8(88.9 \%)$ & $6(85.7 \%)$ & $6(100 \%)$ \\
\hline$\leq 93 \%$ & $1(11.1 \%)$ & $1(14.3 \%)$ & $0(0 \%)$ \\
\hline $\mathrm{SpO}_{2}$ at room air $(\%)^{\mathrm{b}}$ & 95 (92-99) & $95(91-97)$ & $96.5(94-97)$ \\
\hline D-dimer $(\mathrm{ng} / \mathrm{mL})^{\mathrm{b}}$ & $\begin{array}{l}330 \\
(162-1081)\end{array}$ & $\begin{array}{l}463.5 \\
(200-1270)\end{array}$ & $\begin{array}{l}415 \\
(106-962)\end{array}$ \\
\hline Ferritin $(\mathrm{ng} / \mathrm{mL})^{\mathrm{b}}$ & $\begin{array}{l}408 \\
(96.8-1652.8)\end{array}$ & $\begin{array}{l}597 \\
(174-1055.2)\end{array}$ & $\begin{array}{l}411.9 \\
(12.2-1647)\end{array}$ \\
\hline C-Reactive Protein $(\mathrm{mg} / \mathrm{L})^{\mathrm{b}}$ & $\begin{array}{l}16.7 \\
(1.2-120.4)\end{array}$ & $\begin{array}{l}60.7 \\
(2.1-128)\end{array}$ & $\begin{array}{l}32.7 \\
(0.3-120)\end{array}$ \\
\hline $\log _{10}$ copies/ml viral load median (range) ${ }^{\mathrm{b}}$ & $6.3(0-9.7)$ & $6.2(3.8-7)$ & $5.7(0-10.6)$ \\
\hline \multicolumn{4}{|l|}{ Six-point ordinal scale $-\mathrm{N}(\%)$} \\
\hline $2^{\mathrm{d}}$ & 6 & 6 & 4 \\
\hline $3^{\mathrm{e}}$ & 8 & 9 & 11 \\
\hline
\end{tabular}

${ }^{a}$ Daily x 3 consecutive days

${ }^{\mathrm{b}}$ Median (range)

${ }^{c}$ Chronic Obstructive Pulmonary Disease

${ }^{\mathrm{d}}$ Hospital admission, not requiring supplemental oxygen

${ }^{\mathrm{e}}$ Hospital admission, requiring supplemental oxygen 
medRxiv preprint doi: https://doi.org/10.1101/2021.05.25.21257505; this version posted May 25, 2021. The copyright holder for this preprint (which was not certified by peer review) is the author/funder, who has granted medRxiv a license to display the preprint in perpetuity. All rights reserved. No reuse allowed without permission.

Table 2. Plitidepsin-Related Adverse Events

\begin{tabular}{|c|c|c|c|c|c|c|}
\hline \multirow[t]{2}{*}{ Parameter } & \multicolumn{3}{|c|}{ Pre-Amendment ${ }^{\mathrm{a}, \mathrm{b}}$} & \multicolumn{3}{|c|}{ Post-Amendment ${ }^{\mathrm{c}}$} \\
\hline & $\begin{array}{c}\text { Grade } 1 \\
\mathbf{N}(\%)\end{array}$ & $\begin{array}{c}\text { Grade } 2 \\
\mathbf{N}(\%)\end{array}$ & $\begin{array}{c}\text { Grade } 3 \\
\mathbf{N}(\%)\end{array}$ & $\begin{array}{c}\text { Grade } 1 \\
\mathbf{N}(\%)\end{array}$ & $\begin{array}{c}\text { Grade } 2 \\
\mathbf{N}(\%)\end{array}$ & $\begin{array}{c}\text { Grade } 3 \\
\mathrm{~N}(\%)\end{array}$ \\
\hline Nausea & $3(33.3 \%)$ & $2(22.2 \%)$ & - & $11(30.6 \%)$ & $3(8.3 \%)$ & - \\
\hline Vomiting & $2(22.2 \%)$ & - & - & $3(8.3 \%)$ & $2(5.6 \%)$ & - \\
\hline Diarrhea & - & - & - & $1(2.8 \%)$ & $1(2.8 \%)$ & $1(2.8 \%)$ \\
\hline Abdominal Pain & - & - & - & $2(5.6 \%)$ & - & - \\
\hline Dyspepsia & - & - & - & $2(5.6 \%)$ & - & - \\
\hline Asthenia & - & - & - & $1(2.8 \%)$ & $1(2.8 \%)$ & - \\
\hline Anorexia & - & - & - & $1(2.8 \%)$ & - & - \\
\hline Chest Disconfort & - & - & - & $1(2.8 \%)$ & - & - \\
\hline Temperature Regulation Disorder & - & - & - & $1(2.8 \%)$ & - & - \\
\hline Dysthermia & - & - & - & $1(2.8 \%)$ & - & - \\
\hline Anaphylactic Reaction & - & - & $1(11.1 \%)$ & - & - & - \\
\hline Amylase Increase ${ }^{\mathrm{d}}$ & - & - & - & - & $1(2.8 \%)$ & - \\
\hline Lipase Increase $^{\mathrm{e}}$ & - & - & - & - & $1(2.8 \%)$ & - \\
\hline Decreased Appetite & - & - & - & - & $1(2.8 \%)$ & - \\
\hline Dizziness & - & - & - & $2(5.6 \%)$ & - & - \\
\hline Dysgeusia & - & - & - & $2(5.6 \%)$ & - & - \\
\hline
\end{tabular}

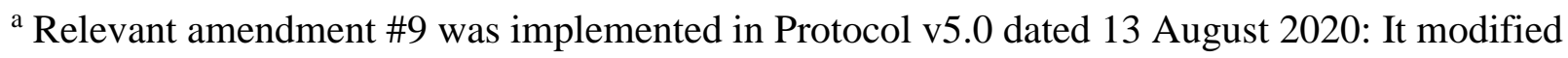
prophylactic medication prior to plitidepsin infusion to add ondansetron $8 \mathrm{mg}$ IV slow infusion and changed the route of administration of dexamethasone, from oral to IV. The dose of dexamethasone was $8 \mathrm{mg}$ (calculated as $8 \mathrm{mg}$ dexamethasone phosphate, which is equivalent to $6.6 \mathrm{mg}$ dexamethasone base).

b 9 patients; 25 plitidepsin IV infusions.

c 36 patients; 108 plitidepsin IV infusions.

${ }^{\mathrm{d}}$ Short lasting, five minutes, retro sternal low intensity pain during 1st day IV infusion: selfresolved plitidepsin infusion completed day 1,2 and 3 .

${ }^{\mathrm{e}}$ Same patient, onset day 2 Plitidepsin Therapy self-resolved in 48 hours. 

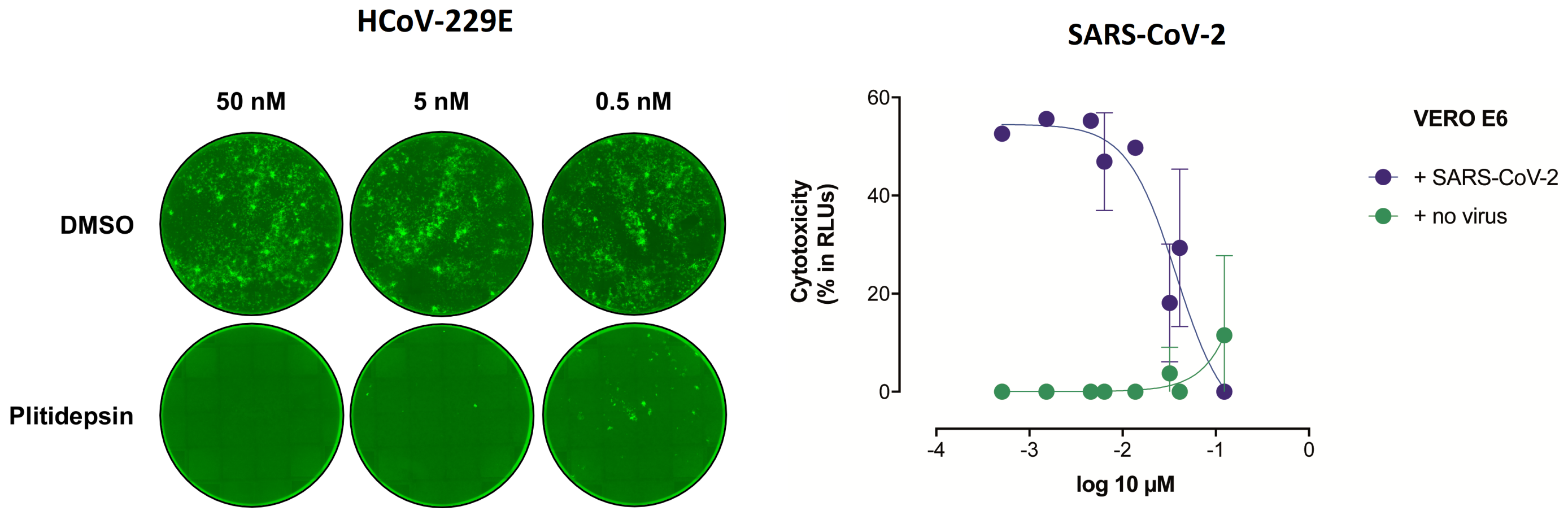

medRxiv preprint doi: https://doi.org/10.1101/2021.05.25.21257505; this version posted May 25, 2021. The copyright holder for this preprint
(which was not certified by peer review) is the authorfunder, who has granted medRxiv a license to display the preprint in perpetuity.

\section{SARS-CoV-2 early virus (VIC) versus B.1.1.7 (UK)}

Plitidepsin

\section{Caco-2}

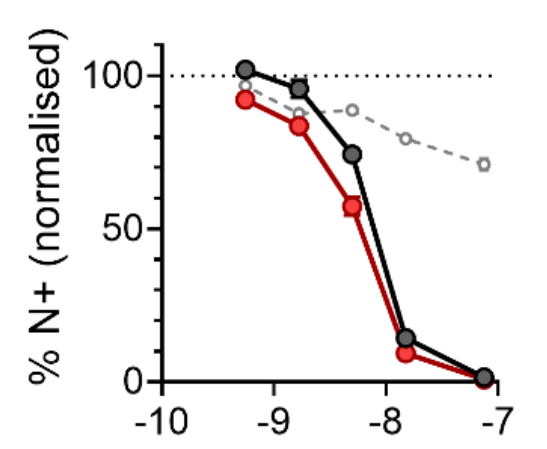

$\log 10$ [plitidepsin (M)]

- VIC01/2020

B. 1.7

- B.1.1.7

- Cell viability

\section{Calu-3}

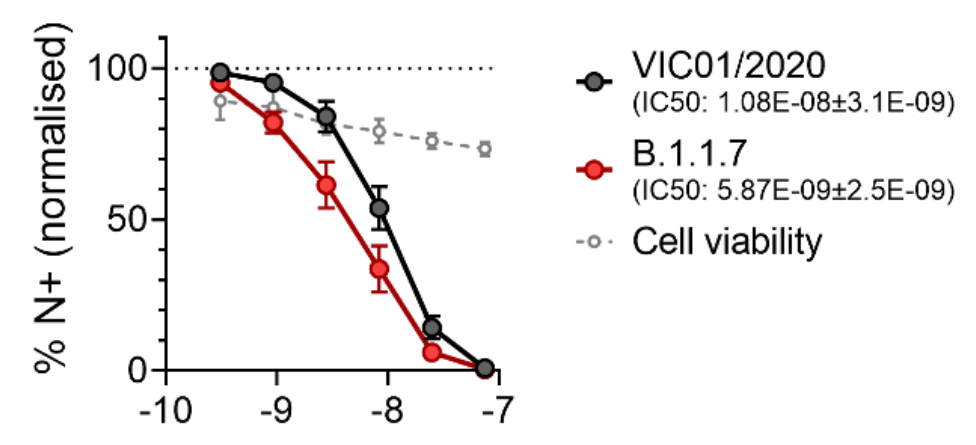

$\log 10$ [plitidepsin (M)]

\section{Remdesivir}

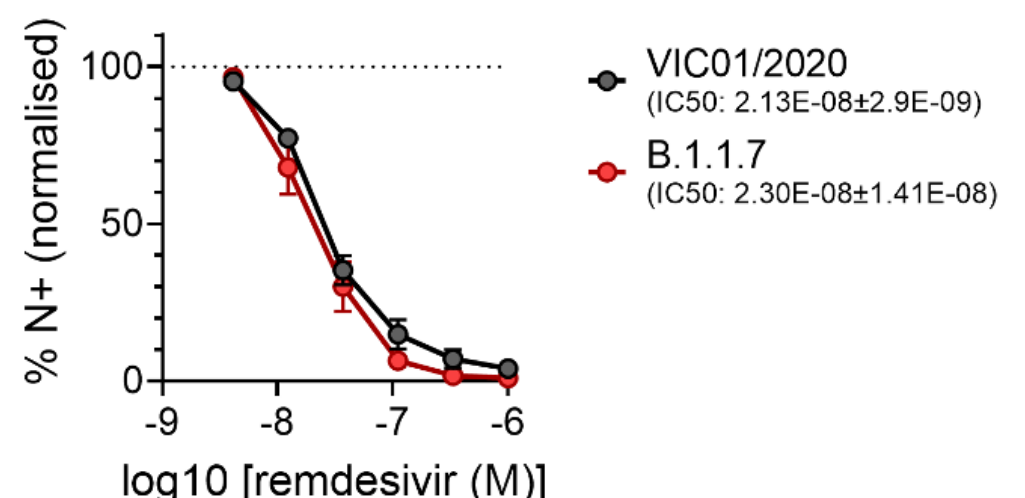

$\log 10$ [remdesivir (M)] 
medRxiv preprint doi: https://doi.org/10.1101/2021.05.25.21257505; this version posted May 25, 2021. The copyright holder for this preprint (which was not certified by peer review) is the author/funder, who has granted medRxiv a license to display the preprint in perpetuity.

Figure 1. Plitidepsin shows strong antiviral activity in vitro against different coronavirus species and variants. (A) HCov-229E-GFP-infected Huh-7 cells were treated with indicated doses of plitidepsin or DMSO. All cells were treated 8 hours after infection and fluorescent foci were analyzed at 48 hours. (B) Cytopathic effect on Vero E6 cells exposed to a fixed concentration of SARS-CoV-2 in the presence of increasing concentrations of plitidepsin. Drug was used at a concentration ranging from $5 \mathrm{nM}$ to $100 \mu \mathrm{M}$. Non-linear fit to a variable response curve from one representative experiment with two replicates is shown (blue), excluding data from drug concentrations with associated toxicity; cytotoxicity in the absence of virus is also shown (green). (C) Calu-3 and Caco-2 cells were pre-treated with remdesivir or plitidepsin at the indicated concentrations or DMSO control at an equivalent dilution for $2 \mathrm{~h}$ before SARS-CoV-2 infection. Cells were harvested after $24 \mathrm{~h}$ for analysis, and viral infection measured by intracellular detection of SARS-CoV-2 nucleoprotein by flow cytometry. Tetrazolium salt (MTT) assay was performed to verify cell viability. 
Dose level (mg as $1.5 \mathrm{~h}$ infusion) $-1.5-2.0-2.5$

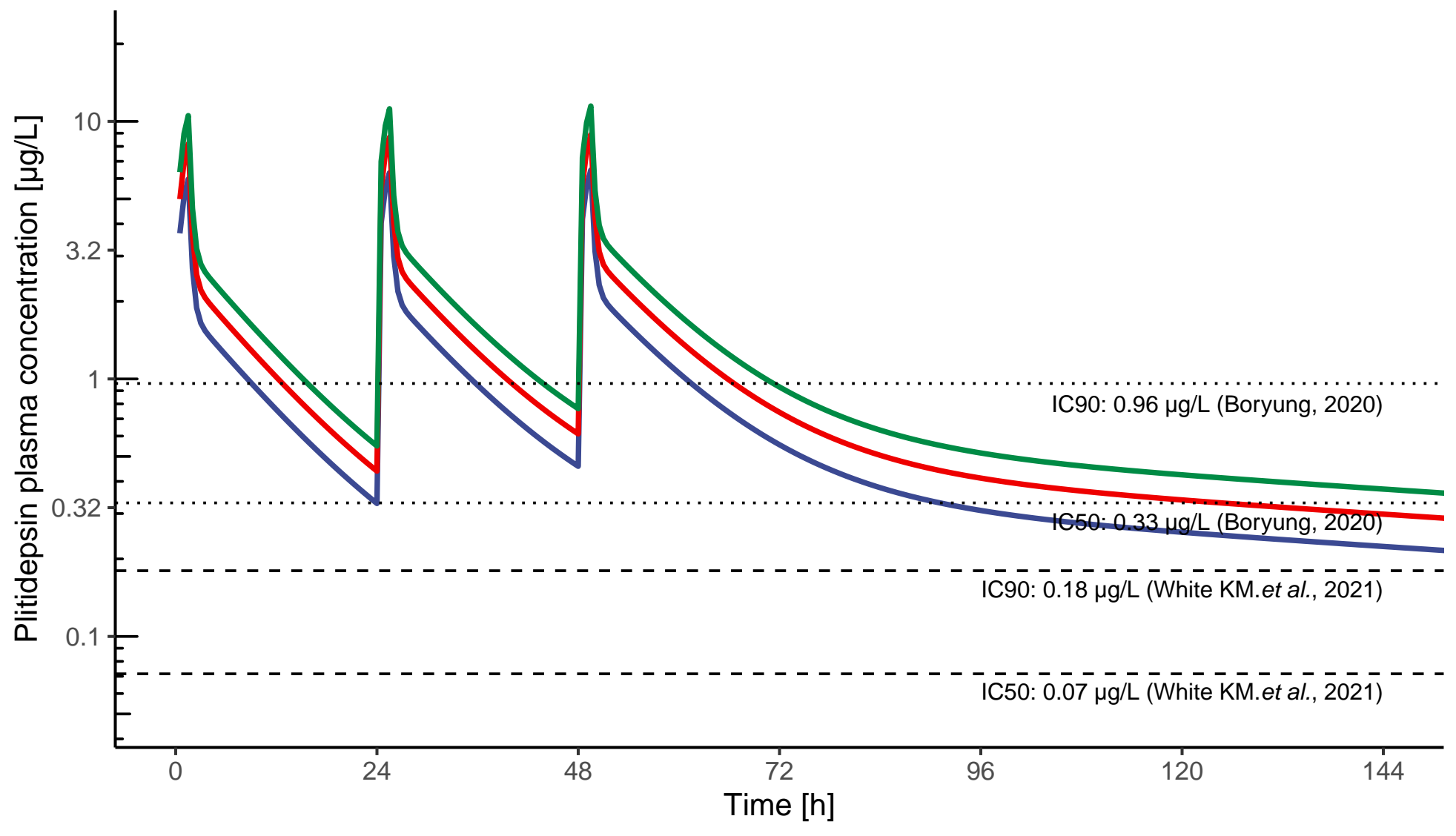


medRxiv preprint doi: https://doi.org/10.1101/2021.05.25.21257505; this version posted May 25, 2021. The copyright holder for this preprint (which was not certified by peer review) is the author/funder, who has granted medRxiv a license to display the preprint in perpetuity.

All rights reserved. No reuse allowed without permission.

Figure 2. Pharmacological estimation of active plasma concentrations of plitidepsin.

Predicted plasma concentrations achieved by a 90 min IV infusion of plitidepsin (1.5, 2 and 2.5 $\mathrm{mg}$ ) and plasma $\mathrm{IC}_{50}$ and $\mathrm{IC}_{90}$ thresholds to assure concentrations in lung above $\mathrm{IC}_{50}$ and $\mathrm{IC}_{90}$ stablished in vitro, respectively. (10, 41). Results from Boryung Pharmaceuticals (Material \& Methods) were obtained first and used to support the study doses and schedule. 

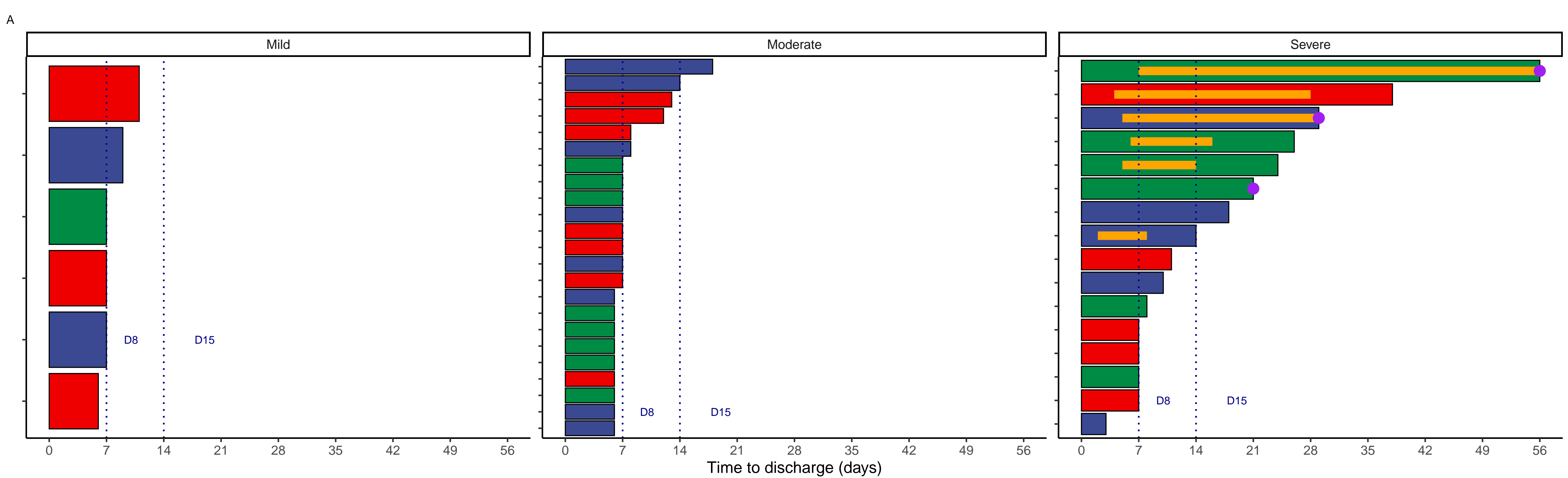

Dose of Plitidepsin $\square 1.5 \mathrm{mg} / \mathrm{day} \square 2 \mathrm{mg} / \mathrm{day} \square 2.5 \mathrm{mg} / \mathrm{day}$
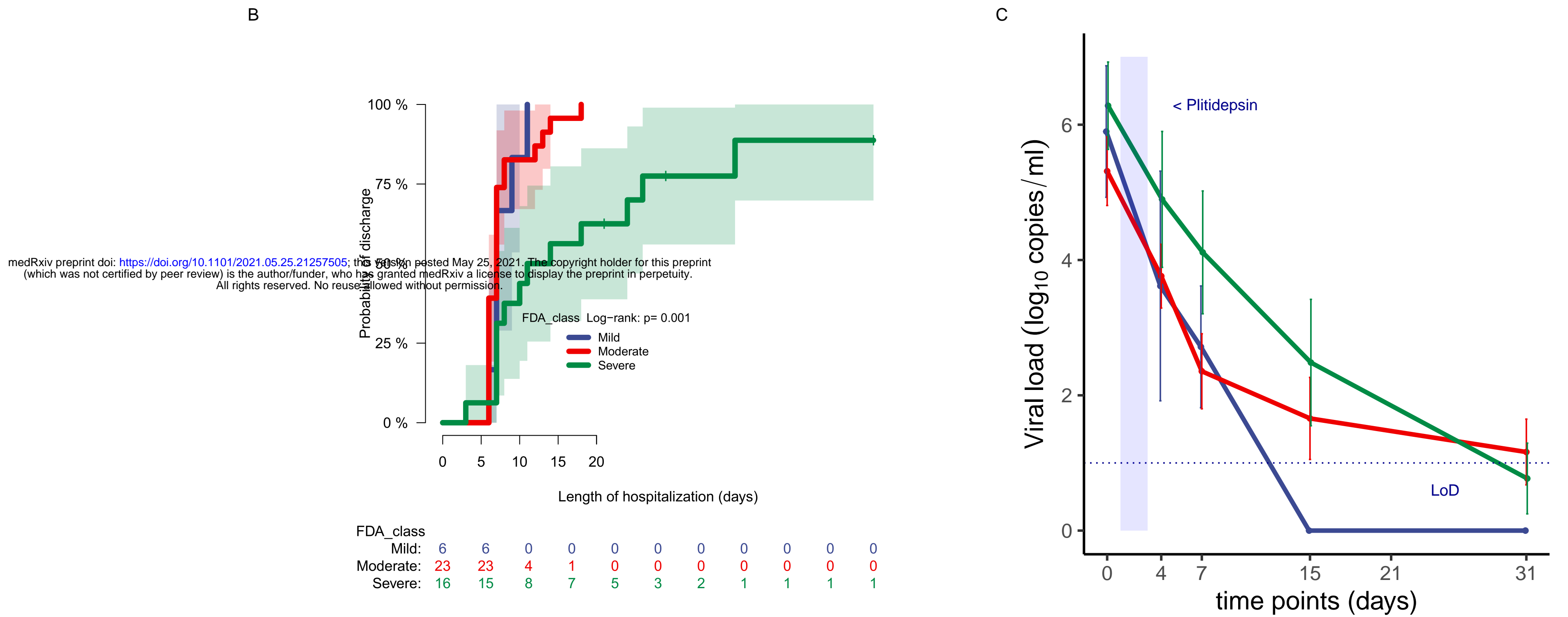

\begin{tabular}{|c|c|c|c|c|}
\hline Baseline co-variable & OR & & Regression Estimate & $p$-value \\
\hline Baseline viral load & 11.482 & $\longmapsto$ & 2.4408 & 0.0224 \\
\hline Dose: $2 \mathrm{mg} / \mathrm{d}$ vs $1.5 \mathrm{mg} / \mathrm{d}$ & 0.268 & $\longmapsto$ & -1.3169 & 0.4165 \\
\hline Dose: $2.5 \mathrm{mg} / \mathrm{d}$ vs $1.5 \mathrm{mg} / \mathrm{d}$ & 0.0233 & $\leftarrow$ & -3.7592 & 0.0561 \\
\hline FDA Moderate vs Mild & 0.0687 & $\longleftrightarrow$ & -2.6784 & 0.2528 \\
\hline FDA Severe vs Mild & 0.7775 & $\longrightarrow$ & -0.2517 & 0.9151 \\
\hline Age (continuous) & 1.238 & 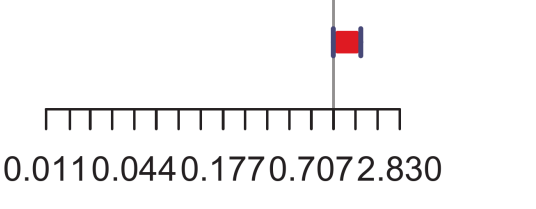 & 0.2135 & 0.0526 \\
\hline
\end{tabular}

DA_class

- Mild

- Mevere

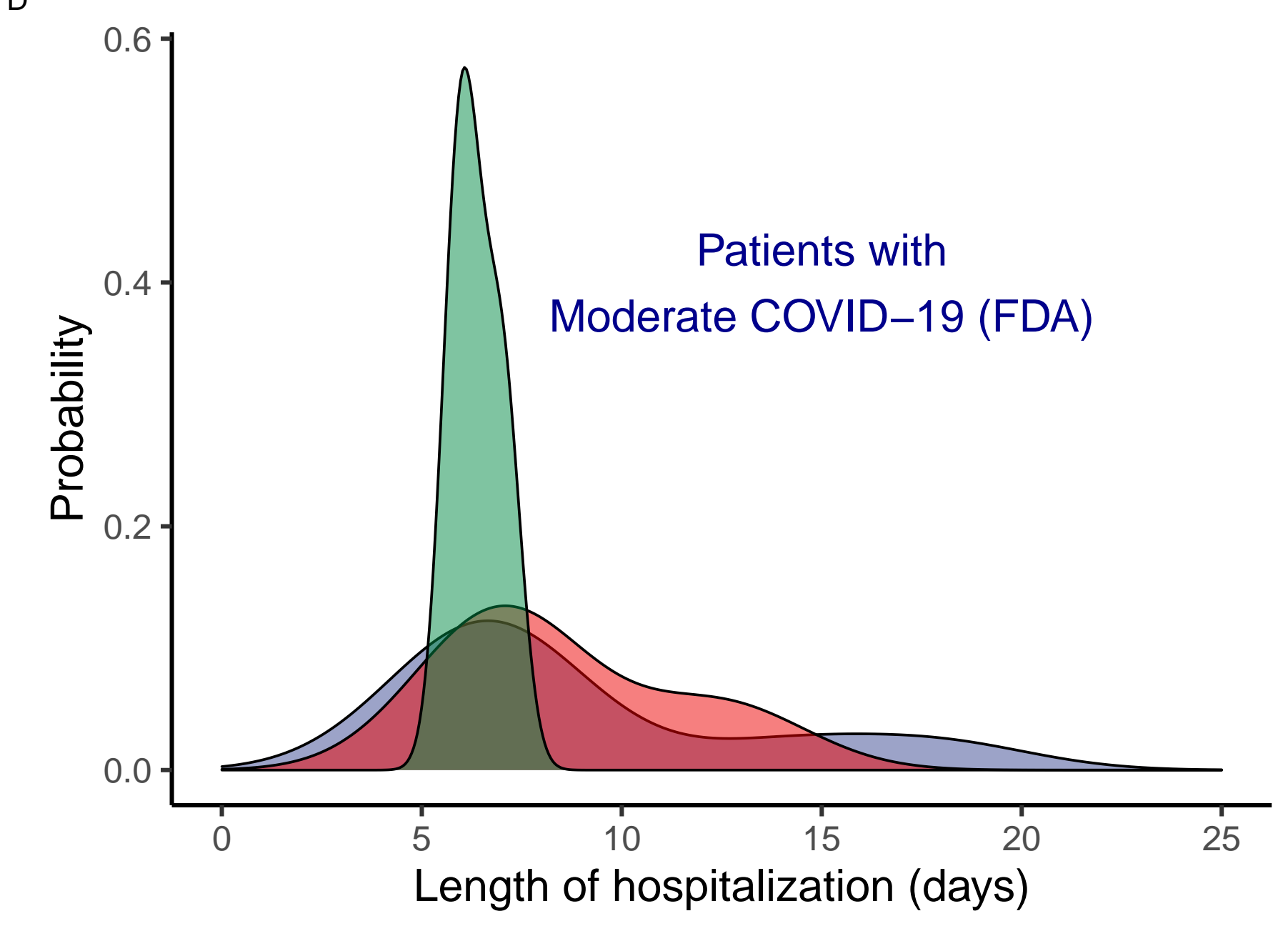

Plitidepsin Dose: $\square 1.5 \mathrm{mg} / \mathrm{day} \square 2 \mathrm{mg} / \mathrm{day} \square 2.5 \mathrm{mg} / \mathrm{day}$

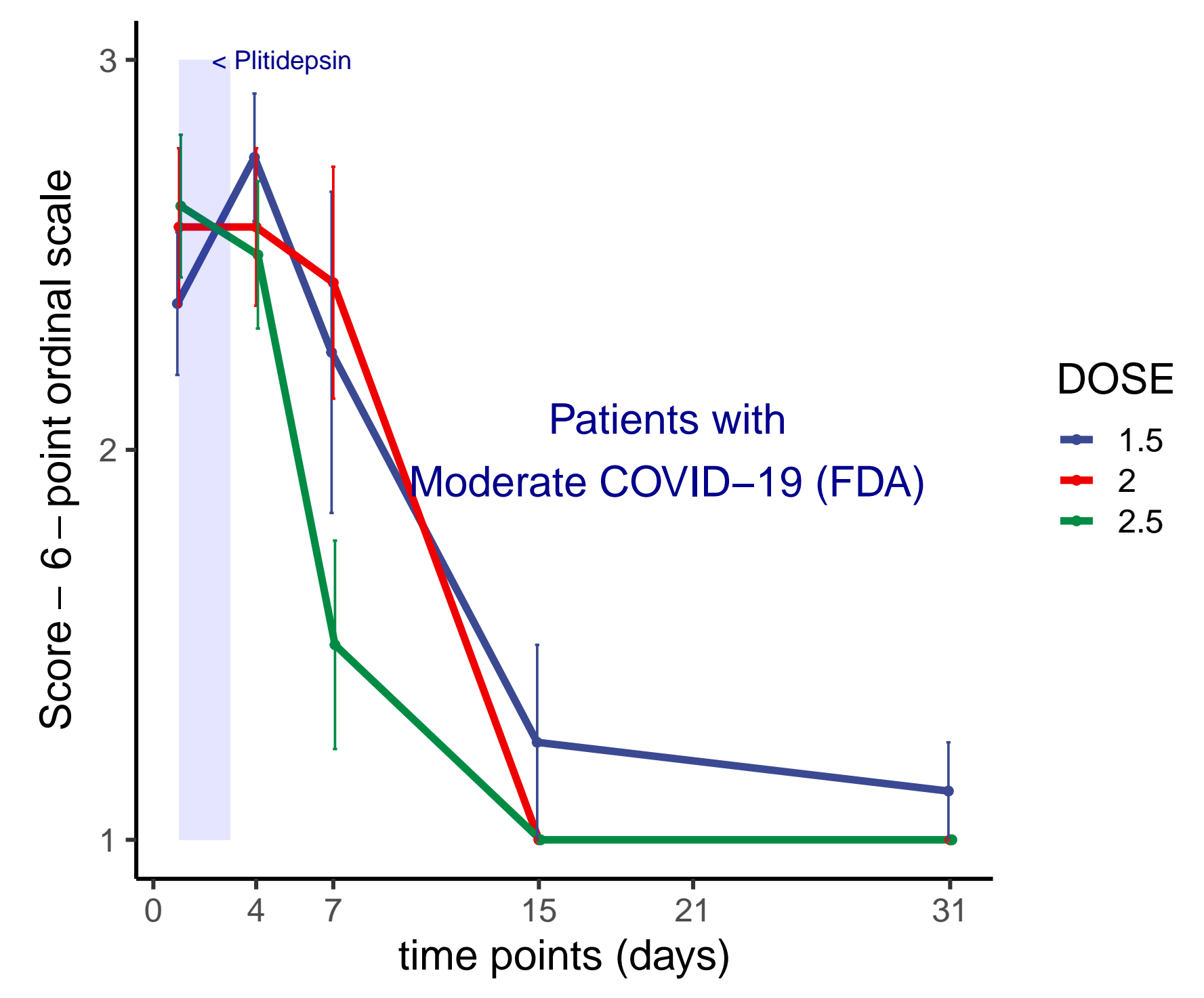


medRxiv preprint doi: https://doi.org/10.1101/2021.05.25.21257505; this version posted May 25, 2021. The copyright holder for this preprint (which was not certified by peer review) is the author/funder, who has granted medRxiv a license to display the preprint in perpetuity.

Figure 3. APLICOV-PC Study: Efficacy Outcomes.

(A) Length of hospitalization, by disease severity at baseline (24) and dose of plitidepsin. Orange bars represent admission in Intensive Care Units. Purple circles represent the three deaths reported in the study. (B) Reverse Kaplan Meier plot showing the cumulative incidence of hospital discharge by baseline severity (mild, moderate or severe COVID-19, according to FDA definition). (24) (C) Viral load kinetics (qRT-PCR from nasopharyngeal exudates), by baseline severity.(24) (D) Temporal distribution of the probability of discharge in patients with moderate COVID-19 at baseline, according to the dose of plitidepsin administered. (E) Exploratory logistic regression model for hospital discharge at Day 8, with selected covariates. Baseline viral load negatively predicts poorer outcome. (F) Mean score over time of the 6-category ordinal scale (25) in patients with moderate disease at baseline, according to the administered dose of plitidepsin. See also Table S5 and Figure S6. 

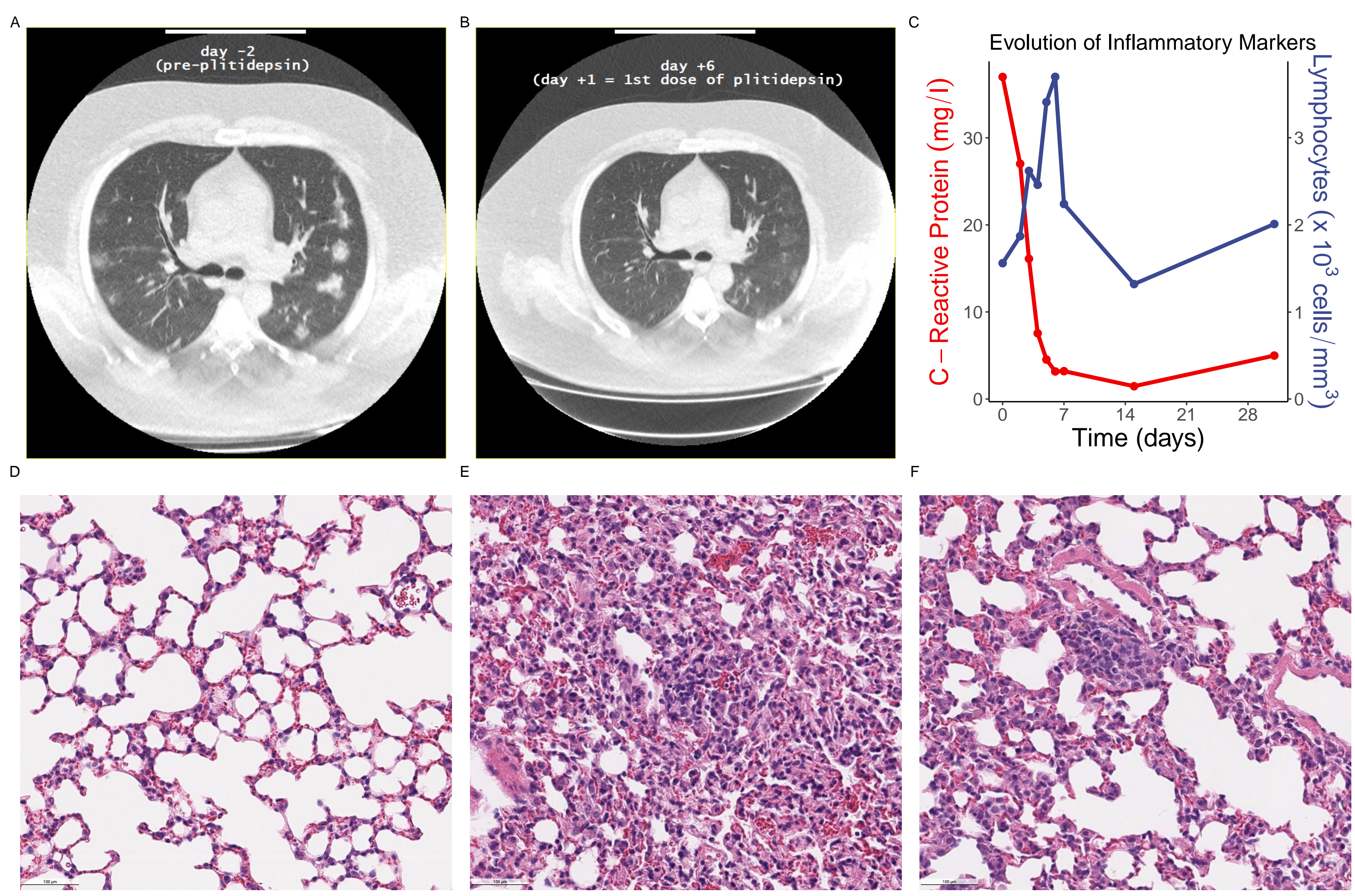
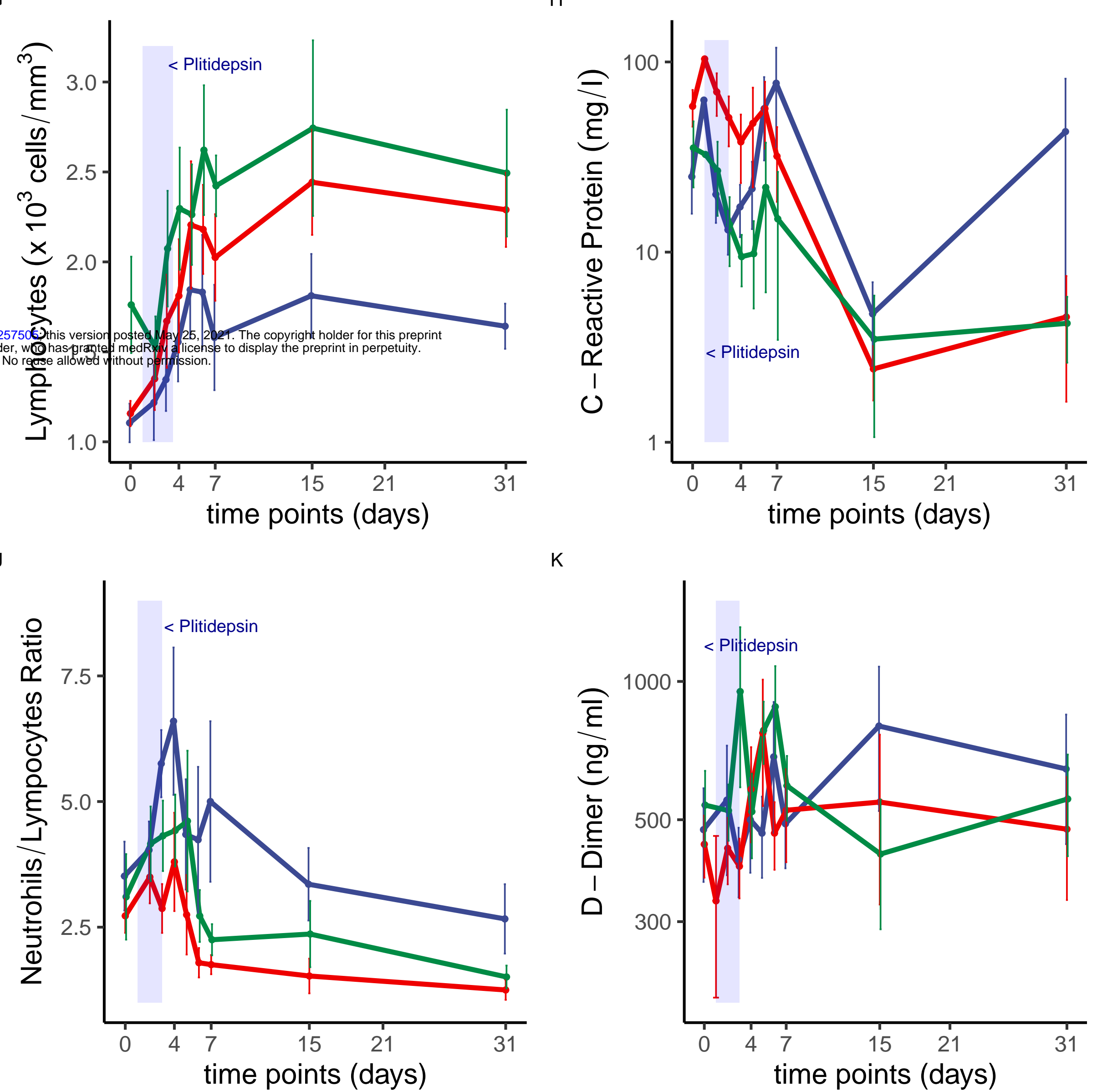
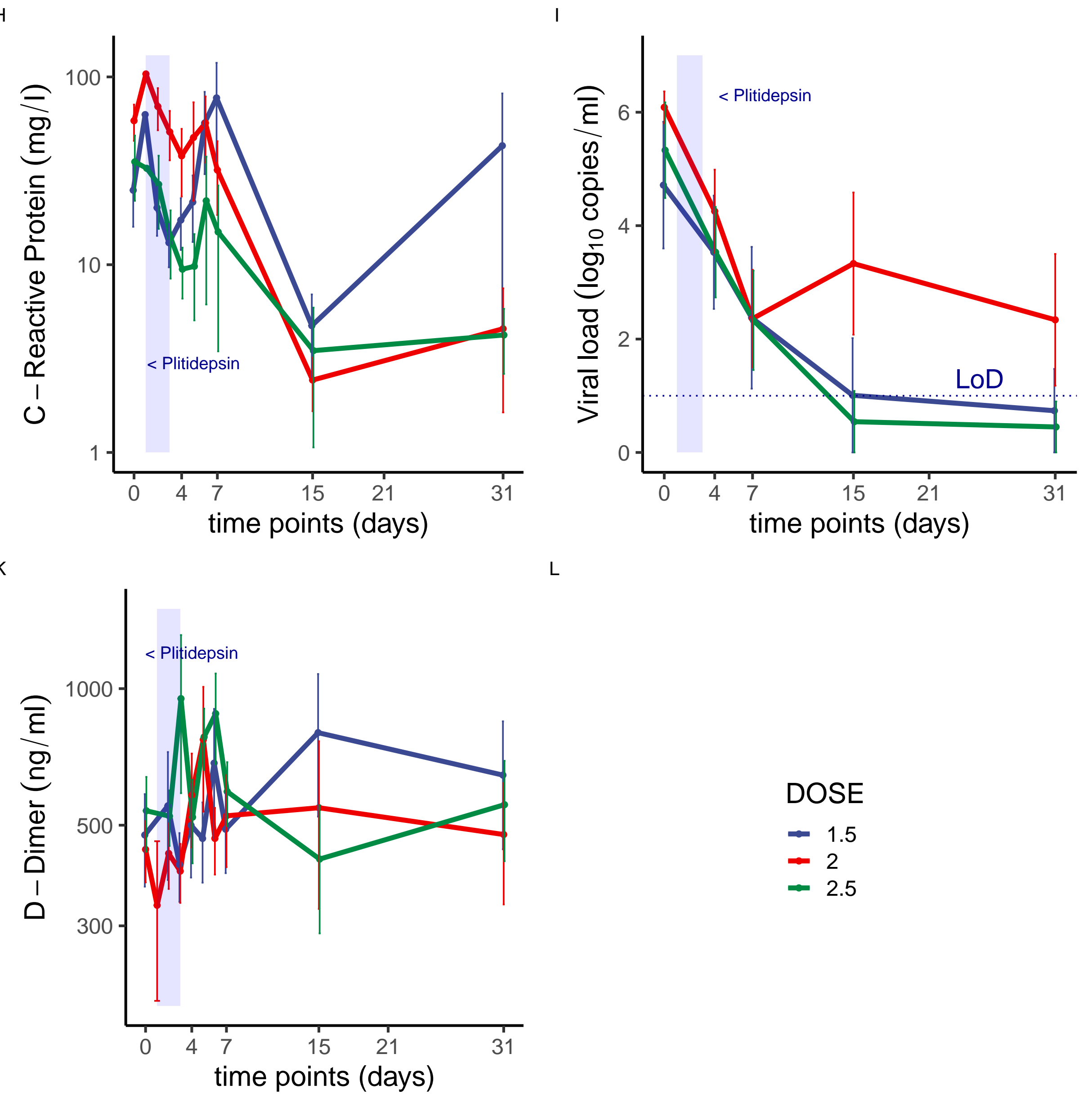
medRxiv preprint doi: https://doi.org/10.1101/2021.05.25.21257505; this version posted May 25, 2021. The copyright holder for this preprint (which was not certified by peer review) is the author/funder, who has granted medRxiv a license to display the preprint in perpetuity.

All rights reserved. No reuse allowed without permission.

Figure 4. Resolution of inflammatory events post-plitidepsin.

(A to $\mathrm{C}$ ) Evolution of a quadragenarian male patient with moderate COVID-19 who required oxygen supplementation at baseline, treated with plitidepsin $2.5 \mathrm{mg} / \mathrm{d}$ : (A \& B) Baseline CT scan shows multiple bilateral lung infiltrates 2 days before treatment (A) that improve on day 6 after start of plitidepsin (B); (C) Rapid recovery of abnormal C-reactive protein (CRP) and increase in absolute lymphocyte count in the same patient. Patient was discharged at day 7 (day 1 is the date of the $1^{\text {st }}$ dose of plitidepsin).

(D to F) Murine model showing lung alveoli from a non-infected mouse (D), alveolar inflammation in a SARS-CoV-2-infected mouse receiving vehicle (E), and alveolar inflammation in a SARS-CoV-2 infected mouse receiving plitidepsin (F). Plitidepsin reduces lung damage, as reported in (10)

( $\mathrm{G}$ to $\mathrm{K}$ ) Patients receiving plitidepsin showed improvement over time in several parameters related to infection and inflammation, including lymphocyte counts $(\mathrm{G}), \mathrm{CRP}(\mathrm{H})$, viral load (I), neutrophil to lymphocyte ratio (J), and D-dimers. LoD - Limit of detection 
medRxiv preprint doi: https://doi.org/10.1101/2021.05.25.21257505; this version posted May 25, 2021. The copyright holder for this preprint (which was not certified by peer review) is the author/funder, who has granted medRxiv a license to display the preprint in perpetuity.

All rights reserved. No reuse allowed without permission.

\section{References and Notes}

1. World Health Organization W. WHO COVID-19 Dashboard. Available online: https://covid19.who.int/ (last cited: [11 Apr 2021]).2021 [

2. Liu CH, Lu CH, Wong SH, Lin LT. Update on Antiviral Strategies Against COVID-19: Unmet Needs and Prospects. Front Immunol. 2020;11:616595.

3. Woo PCY, Lau SKP, Li KSM, Poon RWS, Wong BHL, Tsoi H-w, et al. Molecular diversity of coronaviruses in bats. Virology. 2006;351(1):180-7.

4. Menachery VD, Yount BL, Debbink K, Agnihothram S, Gralinski LE, Plante JA, et al. A SARS-like cluster of circulating bat coronaviruses shows potential for human emergence. Nature Medicine. 2015;21(12):1508-13.

5. Menachery VD, Yount BL, Sims AC, Debbink K, Agnihothram SS, Gralinski LE, et al. SARS-like WIV1-CoV poised for human emergence. Proceedings of the National Academy of Sciences. 2016;113(11):3048.

15 6. Lang AS, Rise ML, Culley AI, Steward GF. RNA viruses in the sea. FEMS Microbiology Reviews. 2009;33(2):295-323.

7. Rinehart KL, Jr., Gloer JB, Hughes RG, Jr., Renis HE, McGovren JP, Swynenberg EB, et al. Didemnins: antiviral and antitumor depsipeptides from a caribbean tunicate. Science. 1981;212(4497):933-5.

8. Canonico PG, Pannier WL, Huggins JW, Rienehart KL. Inhibition of RNA viruses in vitro and in Rift Valley fever-infected mice by didemnins A and B. Antimicrob Agents Chemother. 1982;22(4):696-7.

9. Losada A, Muñoz-Alonso MJ, García C, Sánchez-Murcia PA, Martínez-Leal JF, Domínguez JM, et al. Translation Elongation Factor eEF1A2 is a Novel Anticancer Target for the Marine Natural Product Plitidepsin. Scientific reports. 2016;6:35100-.

10. White KM, Rosales R, Yildiz S, Kehrer T, Miorin L, Moreno E, et al. Plitidepsin has potent preclinical efficacy against SARS-CoV-2 by targeting the host protein eEF1A. Science. 2021:eabf4058.

11. Mateyak MK, Kinzy TG. eEF1A: thinking outside the ribosome. J Biol Chem. 2010;285(28):21209-13.

12. Wei T, Li D, Marcial D, Khan M, Lin MH, Snape N, et al. The eukaryotic elongation factor $1 \mathrm{~A}$ is critical for genome replication of the paramyxovirus respiratory syncytial virus. PLoS One. 2014;9(12):e114447.

13. Zhang X, Shi H, Chen J, Shi D, Li C, Feng L. EF1A interacting with nucleocapsid protein of transmissible gastroenteritis coronavirus and plays a role in virus replication. Veterinary microbiology. 2014;172(3-4):443-8.

14. Maroun JA, Belanger K, Seymour L, Matthews S, Roach J, Dionne J, et al. Phase I study of Aplidine in a dailyx 5 one-hour infusion every 3 weeks in patients with solid tumors refractory to standard therapy. A National Cancer Institute of Canada Clinical Trials Group study: NCIC CTG IND 115. Ann Oncol. 2006;17(9):1371-8.

15. Izquierdo MA, Bowman A, Garcia M, Jodrell D, Martinez M, Pardo B, et al. Phase I clinical and pharmacokinetic study of plitidepsin as a 1-hour weekly intravenous infusion in patients with advanced solid tumors. Clinical cancer research : an official journal of the American Association for Cancer Research. 2008;14(10):3105-12. 
medRxiv preprint doi: https://doi.org/10.1101/2021.05.25.21257505; this version posted May 25, 2021. The copyright holder for this preprint (which was not certified by peer review) is the author/funder, who has granted medRxiv a license to display the preprint in perpetuity.

All rights reserved. No reuse allowed without permission.

17. Anthoney A, Paz-Ares L, Twelves C, al. e, editors. Phase I and pharmacokinetic (PK) study of aplidine (APL) using a 24-hour, weekly schedule. Proc Am Soc Clin Oncol 2000; 19:189a (abstr 734)2000: .

18. Ciruelos Gil EM, Twelves C, Dominguez MJ, Mckay H, Anthony A, Castellanos D, et al., editors. Phase I clinical and pharmacokinetic study of the marine compound aplidine (APL) administered as a 3 hour infusion every 2 weeks. Proc Am Soc Clin Oncol 2002; 21:106a (abstr 422)2002.

19. Spicka I, Ocio EM, Oakervee HE, Greil R, Banh RH, Huang SY, et al. Randomized phase III study (ADMYRE) of plitidepsin in combination with dexamethasone vs. dexamethasone alone in patients with relapsed/refractory multiple myeloma. Ann Hematol. 2019;98(9):2139-50.

20. Therapeutic Goods Administration T. AusPAR: Plitidepsin (Australian Public Assessment Report) https://www.tga.gov.au/auspar/auspar-plitidepsin [updated 08 July 2019. 21. Rodon J, Muñoz-Basagoiti J, Perez-Zsolt D, Noguera-Julian M, Paredes R, Mateu L, et al. Identification of Plitidepsin as Potent Inhibitor of SARS-CoV-2-Induced Cytopathic Effect After a Drug Repurposing Screen. Frontiers in pharmacology. 2021;12(278).

22. Baker EH, Gnjidic D, Kirkpatrick CMJ, Pirmohamed M, Wright DFB, Zecharia AY. A call for the appropriate application of clinical pharmacological principles in the search for safe and efficacious COVID-19 (SARS-COV-2) treatments. Br J Clin Pharmacol. 2020;87:707-11. 23. Nalda-Molina R, Valenzuela B, Ramon-Lopez A, Miguel-Lillo B, Soto-Matos A, PerezRuixo JJ. Population pharmacokinetics meta-analysis of plitidepsin (Aplidin) in cancer subjects. Cancer Chemother Pharmacol. 2009;64(1):97-108.

24. COVID-19: Developing Drugs and Biological Products for Treatment or Prevention Guidance for Industry. , (2021). COVID-19: a randomised, double-blind, placebo-controlled, multicentre trial. Lancet (London, England). 2020;395(10236):1569-78.

26. Saber-Ayad M, Saleh MA, Abu-Gharbieh E. The Rationale for Potential Pharmacotherapy of COVID-19. Pharmaceuticals (Basel, Switzerland). 2020;13(5).

27. Gordon DE, Jang GM, Bouhaddou M, Xu J, Obernier K, White KM, et al. A SARS-CoV2 protein interaction map reveals targets for drug repurposing. Nature. 2020;583(7816):459-68.

28. Rodon J, Muñoz-Basagoiti J, Perez-Zsolt D, Noguera-Julian M, Paredes R, Mateu L, et al. Identification of Plitidepsin as Potent Inhibitor of SARS-CoV-2-Induced Cytopathic Effect after a Drug Repurposing Screen. bioRxiv. 2021:2020.04.23.055756.

29. Reuschl AK, Thorne L, Zuliani Alvarez L, Bouhaddou M, Obernier K, Soucheray M, et al. Host-directed therapies against early-lineage SARS-CoV-2 retain efficacy against B.1.1.7 variant. bioRxiv. 2021.

30. Skevaki C, Fragkou PC, Cheng C, Xie M, Renz H. Laboratory characteristics of patients infected with the novel SARS-CoV-2 virus. The Journal of infection. 2020;81(2):205-12.

31. Macedo A, Gonçalves N, Febra C. COVID-19 fatality rates in hospitalized patients: systematic review and meta-analysis. Ann Epidemiol. 2021;57:14-21.

32. Lalueza A, Lora-Tamayo J, Maestro-de la Calle G, Folgueira MD, Arrieta E, de MiguelCampo B, et al. A Predictive Score at Admission for Respiratory Failure Among Hospitalized Patients with Confirmed 2019 Coronavirus Disease: A Simple Tool for a Complex Problem. Available at SSRN: https://ssrncom/abstract=3618216 or http://dxdoiorg/102139/ssrn3618216. 2020. 
medRxiv preprint doi: https://doi.org/10.1101/2021.05.25.21257505; this version posted May 25, 2021. The copyright holder for this preprint (which was not certified by peer review) is the author/funder, who has granted medRxiv a license to display the preprint in perpetuity.

All rights reserved. No reuse allowed without permission.

33. Berenguer J, Ryan P, Rodríguez-Baño J, Jarrín I, Carratalà J, Pachón J, et al. Characteristics and predictors of death among 4035 consecutively hospitalized patients with COVID-19 in Spain. Clinical Microbiology and Infection. 2020;26(11):1525-36.

34. Rodriguez-Gonzalez CG, Chamorro-de-Vega E, Valerio M, Amor-Garcia MA, Tejerina F, Sancho-Gonzalez M, et al. COVID-19 in hospitalised patients in Spain: a cohort study in Madrid. International Journal of Antimicrobial Agents. 2021;57(2):106249.

35. Muñoz-Rodríguez JR, Gómez-Romero FJ, Pérez-Ortiz JM, López-Juárez P, Santiago JL, Serrano-Oviedo L, et al. Characteristics and Risk Factors Associated With Mortality in a Multicenter Spanish Cohort of Patients With COVID-19 Pneumonia. Archivos de bronconeumologia. 2021.

36. Casas-Rojo JM, Antón-Santos JM, Millán-Núñez-Cortés J, Lumbreras-Bermejo C, Ramos-Rincón JM, Roy-Vallejo E, et al. Clinical characteristics of patients hospitalized with COVID-19 in Spain: Results from the SEMI-COVID-19 Registry. Rev Clin Esp. 2020;220(8):480-94.

15 37. Fajnzylber J, Regan J, Coxen K, Corry H, Wong C, Rosenthal A, et al. SARS-CoV-2 viral load is associated with increased disease severity and mortality. Nature Communications. 2020;11(1):5493.

38. Bertsimas D, Lukin G, Mingardi L, Nohadani O, Orfanoudaki A, Stellato B, et al. COVID-19 mortality risk assessment: An international multi-center study. PLoS One. 2020;15(12):e0243262.

39. Morande PE, Zanetti SR, Borge M, Nannini P, Jancic C, Bezares RF, et al. The cytotoxic activity of Aplidin in chronic lymphocytic leukemia (CLL) is mediated by a direct effect on leukemic cells and an indirect effect on monocyte-derived cells. Invest New Drugs. 2012;30(5):1830-40.

40. Jafarzadeh A, Chauhan P, Saha B, Jafarzadeh S, Nemati M. Contribution of monocytes and macrophages to the local tissue inflammation and cytokine storm in COVID-19: Lessons from SARS and MERS, and potential therapeutic interventions. Life Sci. 2020;257:118102. 41. Kim S, Lee J. Boryung [Data on File]. Evaluation of antiviral activity of plitidepsin (Aplidin) against SARS-CoV-2. Study IPKBR-20200512. 2020:14. 